\title{
Integrated Traditional Learning Model (TLM) or Cooperative (CLM) with the Motivational Level towards Understanding the Concept and Scientific Reasoning Skills in Electrochemistry for Form 4 Students among 3 Schools in LMS Area
}

\author{
M. A. Yahaya, A. N. Mohd Zin \\ (Pusat Pengajian Ilmu Pendidikan, Universiti Sains Malaysia, Pulau Pinang, Malaysia)
}

\begin{abstract}
This paper will discuss about the performance of 96 of 16-yrs old students in learning Electrochemistry. The samples were chosen from 3 schools around LMS area in Perak, Malaysia. Two Learning Model, Traditional and Cooperative were chosen. Three Tests were conducted Pre- and Post were Logical Thinking (LT), Scientific Reasoning Skills (SRS) and Electrochemistry Final Exam (EFE). The T\&L sessions were conducted out from formal class period. The contents of the syllabus were based on Malaysia Ministry of Education. The analysis of data using One-Way ANOVA Test is valid to Learning Model (LM), Motivational Level (ML). Results showed $p>0.05$ showed that Factor $(F)$ had no significant influence on DV. One-Way Repeated ANOVA Test was conducted for evaluating Pre- and Post-Tests. Research findings showed there are improvements in LT, SRS and EFE after treatments were given.
\end{abstract}

Keywords: Electrochemistry Form 4; Logical Thinking (LT); Motivational Level (ML); Scientific Reasoning Skills (SRS); Traditional, Cooperative Learning Model (TLM, CLM)

\section{INTRODUCTION}

Traditional Learning Model (TLM) promotes teacher just give lectures, while students hearing. There are no discussions. While Cooperative Learning Model (CLM) is different. Students will discuss, asking, answer and give their opinions. They are active learners. But, CLM need more time compared to TLM. Time management is so important during discussion due to not every members will discipline them. Sometimes, the discussion will be out of the topic, Electrochemistry. The T \& L sessions in learning Electrochemistry with assimilation of Logical Thinking (LT) and Scientific Reasoning Skills (SRS). There are 12 LT and 10 SRS questions were built related to EFE. Students were trained to give scientific explanations based on Electrochemistry concepts they were learnt. While the LT function to facilitate their memory based on contextual learning, the ideas related to Electrochemistry they can see in everyday life.

\section{EXPERIMENTAL}

\subsection{Respondents}

Initially, about 150 of students were chosen from 3 schools around LMS, Perak, Malaysia to participate in this programme. But then, only 96 of 16 yrs old respondents were left. The schools involve are SMK Bukit Jana, SMK Dr. Burhanuddin, and SMK Kamunting. There are about 4-5 members in a CLM group each.

\subsection{Research Hypotheses}

$\mathrm{H}_{1}$ : Learning Model (LM) influences the students' performance in Post-LT, -SRS and -EFE.

$\mathrm{H}_{2}$ : Motivational Level (ML) influences the students' performance in Post-LT, -SRS and -EFE.

$\mathrm{H}_{3}$ : Pre-Tests influence the students' performance in Post-LT, -SRS and -EFE.

\subsection{Learning Model (LM)}

2 LM were chosen, traditional and cooperative. The TLM was conducted in large group. The respondents in CLM were divided into 4-5 small groups during T \& $\mathrm{L}$.

\subsection{Tests}

3 tests were conducted - LT, SRS and EFE as presented in Section 3.1, Table 1. Pre-Tests were given initially. Then, students involved into T \& L. After finished, the Post-Tests will be given. In this study, students must have multiple intelligences, consist of mathematical logical, language, visual and space, interpersonal and intrapersonal. Another test for cooperative groups is Groups' Compatibility (GC) Test. 25 questions related to their peers were given. Students got less $75 \%$ will be change to other groups. Motivational Level (ML) Test is also given. The Motivational Level assessed the 5 dimensions of students' motivation in learning Electrochemistry through: (1) self-efficacy, (2) scientific learning value, (3) goal, (4) epistemological beliefs 
and (5) test anxiety. The 5-point Likert-type scale, from (5) strongly agree to (1) strongly disagree were used to get their opinions in 35 questions [1].

\subsection{T\&L Sessions}

The T\&L sessions were done in 4 sessions for 4 weeks. Every week, there was at least once T\&L session with the presence of researchers. The activities inside this programme are: (1) lecture session about Electrochemistry overally, (2) Electrolytic and Galvanic Cells - Components and How They Works?, (3) Electrochemical Series and Games, and lastly training how to give answer with scientific explanations by using (4) Worksheet about Electrochemistry. All the T\&L sessions were done for both TLM and CLM but there was an extra for CLM, which is training session for Group Instructors (GI). All the GI were prepared with Electrochemistry Manual Programmes while others not.

\subsection{Data Analyzing}

The data analysing is using IBM SPSS Statistics Software 20.0. The One Way ANOVA or Repeated Tests were used to analyze the data. The normality and homogeneity of regression slopes were first determined before the One Way ANOVA and ANOVA Repeated Measurements is conducted. While the significant value (p) for the Levene or Brown-Forsythe Tests also must be $>0.05$ [2]. So, the data were normally distributed and homogeneity of variances has been met.

\subsection{Preparation of Tests}

\section{RESULTS AND DISCUSSION}

The components of tests questions as in Table 1.

Table 1. The Questions in LT and SRS Tests related to Electrochemistry concepts.

\begin{tabular}{|l|l|c|c|}
\hline No. & Electrochemistry Concepts & No. of Questions in LT & No. of Questions in SRS \\
\hline 1 & Same charges repel & 1 & 1 \\
\hline 2 & Same magnet polar repel & 2 & 2 \\
\hline 3 & Dissolving rate = Deposition rate & 3 & 3 \\
\hline 4 & Stirring effect & 4 & 4 \\
\hline 5 & Ion affinity towards electrodes & 5 & 5 \\
\hline 6 & $\begin{array}{l}\text { Effects of level differences in Electrochemical } \\
\text { Series (ES) }\end{array}$ & 6 & 6 \\
\hline 7 & Anion will be attracted to cathode & 7 & 2 \\
\hline 8 & Galvanic cell do not have electrical sources & 8 & 6 \\
\hline 9 & Electrolysis of Compounds & 9 & - \\
\hline 10 & Electrical conductivity & 10 & 9 \\
\hline 11 & Inert vs. active & 11 & 9 \\
\hline 12 & Negative terminal for Galvanic Cell & 12 & 9 \\
\hline 13 & Neutralisation of ions & - & \\
\hline 14 & Oxidation number & - & \\
\hline
\end{tabular}

3.1.1 The Electrochemistry Concepts: Inert vs. Active Substances/Negative Terminal for Galvanic Cell. The examples for LT and SRS questions as follow:

a) LT Question No. 11:

Based on Figure 1, which object can be dissolved in water?

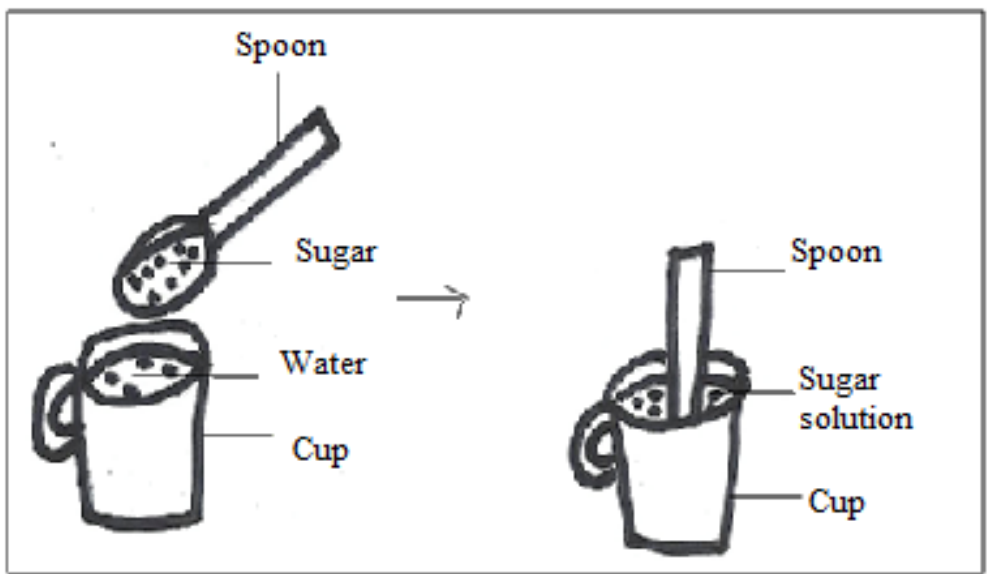

Figure 1. Sugar dissolves in water. 
b) SRS Question No. 9.

$100 \mathrm{~g}$ of sugar each in crystal or cube form were dissolved in water with uniform stirring rate as in Figure 2. At $15 \mathrm{~s}$, all sugar crystal was dissolved completely in Beaker B. While all sugar cubes were dissolved completely at $35 \mathrm{~s}$. Which forms of sugar dissolved completely faster?

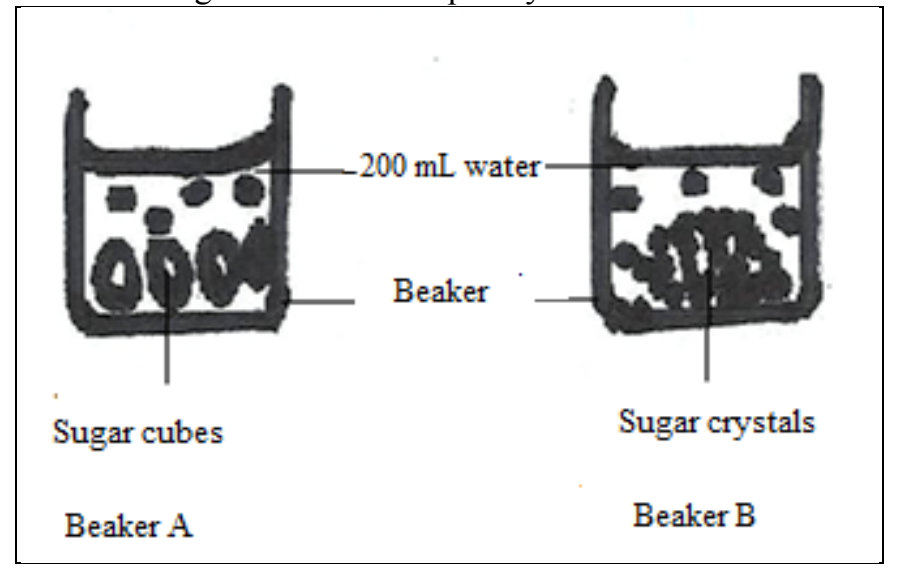

Figure 2. Sugar in crystal and cubes form dissolved in $200 \mathrm{~mL}$ of water each.

All the questions in EFE are in Higher Order Thinking Skills (HOTS), so need them to predict and give scientific explanations. The use of analogies based on something occurred in their everyday life which related to Electrochemistry concepts will make sense to their learning [3].

By using analogy, students need to assimilate and accommodate their existing conceptions or personal experiences into other situations in Post-EFE. They need to give scientific explanation based on SRS that were given [4, 5]. 2 from 7 strategies supposed by Cordellichio and Field (1997) in training brain are finding similarity when using analogies and analysing opinions by sharing ideas [6].

\subsection{One-Way ANOVA Test}

Table 2. The results for Levene and Brown-Forsythe Tests using LM as IV.

\begin{tabular}{|l|l|l|l|l|l|c|c|c|}
\hline \multirow{2}{*}{ DV } & \multicolumn{3}{|c|}{ Levene Test } & \multicolumn{3}{c|}{ Brown-Forsythe Test } \\
\cline { 2 - 9 } & $\begin{array}{l}\text { Levene } \\
\text { Statistic }\end{array}$ & df1 & df2 & $\begin{array}{l}\text { Brown- } \\
\text { Forsythe } \\
\text { Statistic }\end{array}$ & df1 & Sig. \\
\hline Post-LT & 2.111 & 1 & 94 & 0.150 & 0.245 & 1 & 70.261 & 0.622 \\
\hline Post-SRS & 10.588 & 1 & 94 & 0.002 & 2.804 & 1 & 87.486 & 0.098 \\
\hline Post-EFE & 2.728 & 1 & 94 & 0.102 & 0.295 & 1 & 90.473 & 0.588 \\
\hline
\end{tabular}

The Levene Test for Post-SRS gave $p<0.05$, indicated that the homogeneity of variances had been violated. While using Brown-Forsythe Test, all the $\mathrm{p}>0.05$ for Post-LT, -SRS and -EFE indicated that all the homogeneity of variances had been met (as can be seen in Table 2).

Table 3. Descriptive Statistics for students' scores on Post-LT, -SRS, and -EFE using TLM and CLM.

\begin{tabular}{|l|c|c|c|c|c|c|}
\hline \multirow{2}{*}{ DV } & TLM & \multicolumn{5}{l|}{ CLM } \\
\cline { 2 - 7 } & Mean & Std. Deviation & N & Mean & Std. Deviation & N \\
\hline Post-LT & 17.91 & 3.872 & 43 & 17.57 & 2.576 & 53 \\
\hline Post-SRS & 15.16 & 3.477 & 43 & 16.75 & 5.744 & 53 \\
\hline Post-EFE & 12.74 & 4.243 & 43 & 13.34 & 6.439 & 53 \\
\hline
\end{tabular}

The descriptive statistics of students' scores on Post-LT, -SRS, and -EFE as can be seen in Table 3. The mean scores become more less from Post-LT to -EFE for both TLM and CLM. This indicated that although students' LT is more, their performance in SRS and EFE are still not increased. The Electrochemistry Form 4 Manual is given only to Groups' Instructors. Students' said they did not have enough time to take note during T \& L sessions. Researchers have given them Electrochemistry slides during the first T \& L, but that not enough. They did not know how to elaborate the slides outside the class. So, all depend on their GI. If they were very willing to share, so each member in their groups will be success. Their opinion was I should give them a copy of manual for every member. But this will consume much money. 
Table 4. The results for Levene and Brown-Forsythe Tests using ML as IV.

\begin{tabular}{|c|c|c|c|c|c|c|c|c|}
\hline \multirow[t]{2}{*}{ DV } & \multicolumn{4}{|c|}{ Levene Test } & \multicolumn{4}{|c|}{ Brown-Forsythe Test } \\
\hline & $\begin{array}{l}\text { Levene } \\
\text { Statistic }\end{array}$ & df1 & $\mathrm{df} 2$ & Sig. & $\begin{array}{l}\text { Brown- } \\
\text { Forsythe } \\
\text { Statistic }\end{array}$ & df1 & df2 & Sig. \\
\hline Post-LT & 0.217 & 1 & 94 & 0.642 & 1.043 & 1 & 12.975 & 0.326 \\
\hline Post-SRS & 0.369 & 1 & 94 & 0.545 & 0.265 & 1 & 14.607 & 0.614 \\
\hline Post-EFE & 1.409 & 1 & 94 & 0.238 & 0.125 & 1 & 18.141 & 0.728 \\
\hline
\end{tabular}

From Table 4, all the $\mathrm{p}>0.05$, indicated that the homogeneity of variances had been met for all collected data. The Levene and Brown-Forsythe Tests are insensitive to normality, so they are right choice to determine homogeneity of variances compared to Bartlett's Test [7].

Interpersonal intelligence by Howard Gardner (1995) listed 4 good members group behavior such as: (1) listening with empathy, (2) help and built, (3) respect others time and space and (4) positive enhancements. These aspects important to guarantee social skills in that group are done effectively [6]. But in reality, this is hard to achieve. Not every member is good, sometimes they have opposite personality as borders in social skills, plus they are still youngsters. Social skills in groups also can create positive climate such as enhance ML and produce learning competition.

Table 5. Descriptive Statistics for students' scores on Post-LT, -SRS, and -EFE using different ML.

\begin{tabular}{|l|l|c|c|c|c|c|}
\hline \multirow{2}{*}{ Post-Test } & \multicolumn{3}{|c|}{ HML (151-200) } & \multicolumn{3}{c|}{ LML (101-150) } \\
\cline { 2 - 7 } & Mean & Std. Deviation & N & Mean & Std. Deviation & N \\
\hline LT & 17.84 & 3.221 & 11 & 16.82 & 3.093 \\
\hline SRS & 15.96 & 5.030 & 11 & 16.64 & 3.931 \\
\hline EFE & 13.02 & 5.771 & 11 & 13.45 & 3.475 & 85 \\
\hline
\end{tabular}

The Post-SRS score mean value for LML is higher than HML, 16.64 compared to 15.96 although the difference in sample size is large 85 and 11 respectively $[\mathrm{F}(1,94)=0.18, \mathrm{p}>0.05]$ (can be seen in Table 5).

Table 6. One Way ANOVA results for LM as IV.

\begin{tabular}{|l|l|c|c|c|c|c|}
\hline Test & Sum of Squares & df & Mean Square & F & Sig. \\
\hline \multirow{3}{*}{ Post-LT } & Between Groups & 2.759 & 1 & 2.759 & .266 & .607 \\
\cline { 2 - 7 } & Within Groups & 974.647 & 94 & 10.369 & \\
\cline { 2 - 7 } & Total & 977.406 & 95 & & \\
\hline \multirow{3}{*}{ Post-SRS } & Between Groups & 60.162 & 1 & 60.162 & 2.543 & .114 \\
\cline { 2 - 7 } & Within Groups & 2223.672 & 94 & 23.656 & & .272 \\
\cline { 2 - 7 } & Total & 2283.833 & 95 & & .603 \\
\hline \multirow{3}{*}{ Post-EFE } & Between Groups & 8.417 & 1 & 8.417 & & \\
\cline { 2 - 7 } & Within Groups & 2912.073 & 94 & 30.979 & & \\
\cline { 2 - 7 } & Total & 2920.490 & 95 & & & \\
\end{tabular}

Problem aroused when some male respondents quit during half-way of this program occurred. This is due to their absence during programme because of rain and time constrain. School programme so packed during this period. Transportation is also the main factor their absence. This due to this programme can only be done in the evening, after school session finished. They need to go back home first to take lunch. This program had started with limitation budget. Lodewyk K. R. et al. [8] cited that the environment in education must be setting well to increase self-efficacy so that anxiety also will be decreased.

$\mathrm{F}(1,94)=0.266, \mathrm{p}=0.607$ for Post-LT, $\mathrm{F}(1,94)=2.543, \mathrm{p}=0.114$ for Post-SRS, and $\mathrm{F}(1,94)=0.272$, $p=0.603$ for Post-EFE (as can be seen in Table 6). All the p-value for those Post-Tests was above 0.05 showed that insignificant differences among LM towards DV scores.

Students got most scores for Post-LT when using both TLM and CLM (as can be seen in Table 3). Mostly, the $\mathrm{p}>0.05$, so Factor (F) had insignificant influences on Dependant Variable (DV) (as can be seen in Table 6).

Table 7. One Way ANOVA results for ML as IV.

\begin{tabular}{|c|c|c|c|c|c|c|}
\hline \multicolumn{2}{|l|}{ Test } & Sum of Squares & $\mathrm{df}$ & Mean Square & $\mathrm{F}$ & Sig. \\
\hline \multirow{3}{*}{ Post-LT } & Between Groups & 10.076 & 1 & 10.076 & .979 & .325 \\
\hline & Within Groups & 967.330 & 94 & 10.291 & & \\
\hline & Total & 977.406 & 95 & & & \\
\hline \multirow{3}{*}{ Post-SRS } & Between Groups & 4.394 & 1 & 4.394 & .181 & .671 \\
\hline & Within Groups & 2279.440 & 94 & 24.249 & & \\
\hline & Total & 2283.833 & 95 & & & \\
\hline \multirow{3}{*}{ Post-EFE } & Between Groups & 1.809 & 1 & 1.809 & .058 & .810 \\
\hline & Within Groups & 2918.680 & 94 & 31.050 & & \\
\hline & Total & 2920.490 & 95 & & & \\
\hline
\end{tabular}


$\mathrm{F}(1,94)=0.979, \mathrm{p}=0.325$ for Post-LT, $\mathrm{F}(1,94)=0.181, \mathrm{p}=0.671$ for Post-SRS, and $\mathrm{F}(1,94)=0.058$, $\mathrm{p}=0.810$ for Post-EFE (as can be seen in Table 7). All the $\mathrm{p}$-value for those Post-Tests was above 0.05 showed that insignificant influence of ML towards those tests (as can be seen in Table 7). During this programme, students were given prize as positive enhancements to encourage their ML. In CLM groups, there must be at least one High Motivational Level (HML) member to create positive climate during discussions.

\subsection{One-Way Repeated ANOVA Test}

Table 8. Descriptive Statistics Pre- and Post-Tests for LT, SRS and EFE using One Way ANOVA Repeated.

\begin{tabular}{|l|c|c|c|}
\hline Test & Mean & Std. Deviation & N \\
\hline Pre-LT & 17.35 & 2.186 & 96 \\
\hline Post-LT & 17.72 & 3.208 & 96 \\
\hline Pre-SRS & 14.95 & 4.125 & 96 \\
\hline Post-SRS & 16.04 & 4.903 & 96 \\
\hline Pre-EFE & 8.72 & 4.192 & 96 \\
\hline Post-EFE & 13.07 & 5.545 & 96 \\
\hline
\end{tabular}

Table 8 shows the descriptive statistics for Pre- or Post- LT, -SRS and -EFE gave meaning that the students' LT, and SRS is higher than -EFE gave impact that their SRS is higher than conceptual understanding. The -SRS Tests is to evaluate students' SRS while EFE function to examine their conceptual understanding about Electrochemistry. But their mean differences were little. Electrochemistry Form 4 is a complicated topic to be learnt, because many topics in this chapter including in the future topics, such as Oxidation and Reduction, Chapter 3 Form 5 Syllabus. Students still cannot memorize well how to write ionic equations. Also, electrolyte that can be used such as Acids and Bases in Chapter 7 and 8, Form 4 Syllabus. In order to answer well in Electrochemistry, they must understand very well in those topics first [9].

Table 9. Mauchly's Test of Sphericity for measuring LT, SRS and EFE.

\begin{tabular}{|c|c|c|c|c|c|c|c|c|}
\hline \multirow{3}{*}{$\begin{array}{l}\text { Within } \\
\text { Subjects } \\
\text { Effect }\end{array}$} & \multirow[t]{2}{*}{ Measure } & \multirow[t]{2}{*}{ Mauchly's W } & \multirow{2}{*}{$\begin{array}{l}\text { Approx. Chi- } \\
\text { Square }\end{array}$} & \multirow[t]{2}{*}{$\mathrm{df}$} & \multirow[t]{2}{*}{ Sig. } & \multicolumn{3}{|c|}{ Epsilon $^{b}$} \\
\hline & & & & & & $\begin{array}{l}\text { Greenhouse- } \\
\text { Geisser }\end{array}$ & $\begin{array}{l}\text { Huynh- } \\
\text { Feldt }\end{array}$ & $\begin{array}{l}\text { Lower- } \\
\text { bound }\end{array}$ \\
\hline & LT & 1.000 & 0.000 & 0 & . & 1.000 & 1.000 & 1.000 \\
\hline \multirow{2}{*}{ PrePost } & SRS & 1.000 & 0.000 & 0 & . & 1.000 & 1.000 & 1.000 \\
\hline & EFE & 1.000 & 0.000 & 0 & . & 1.000 & 1.000 & 1.000 \\
\hline \multicolumn{9}{|c|}{$\begin{array}{l}\text { Tests the null hypothesis that the error covariance matrix of the orthonormalized transformed dependent variables is proportional } \\
\text { to an identity matrix. }{ }^{\text {a }}\end{array}$} \\
\hline \multicolumn{9}{|c|}{$\begin{array}{l}\text { a. Design: Intercept } \\
\text { Within Subjects Design: PrePost }\end{array}$} \\
\hline
\end{tabular}

Table 10. Univariate Tests for measuring LT, SRS and EFE.

\begin{tabular}{|c|c|c|c|c|c|c|c|}
\hline Source & \multicolumn{2}{|c|}{ Measure } & Type III Sum of & $\mathrm{df}$ & Mean Square & $\mathrm{F}$ & Sig. \\
\hline \multirow{12}{*}{ PrePost } & \multirow{4}{*}{ LT } & Sphericity Assumed & 6.380 & 1 & 6.380 & 1.131 & 0.290 \\
\hline & & Greenhouse-Geisser & 6.380 & 1.000 & 6.380 & 1.131 & 0.290 \\
\hline & & Huynh-Feldt & 6.380 & 1.000 & 6.380 & 1.131 & 0.290 \\
\hline & & Lower-bound & 6.380 & 1.000 & 6.380 & 1.131 & 0.290 \\
\hline & \multirow{4}{*}{ SRS } & Sphericity Assumed & 57.422 & 1 & 57.422 & 5.606 & .020 \\
\hline & & Greenhouse-Geisser & 57.422 & 1.000 & 57.422 & 5.606 & .020 \\
\hline & & Huynh-Feldt & 57.422 & 1.000 & 57.422 & 5.606 & .020 \\
\hline & & Lower-bound & 57.422 & 1.000 & 57.422 & 5.606 & .020 \\
\hline & \multirow{4}{*}{ EFE } & Sphericity Assumed & 910.021 & 1 & 910.021 & 35.992 & .000 \\
\hline & & Greenhouse-Geisser & 910.021 & 1.000 & 910.021 & 35.992 & .000 \\
\hline & & Huynh-Feldt & 910.021 & 1.000 & 910.021 & 35.992 & .000 \\
\hline & & Lower-bound & 910.021 & 1.000 & 910.021 & 35.992 & .000 \\
\hline \multirow{12}{*}{$\begin{array}{l}\text { Error } \\
\text { (PrePost) }\end{array}$} & \multirow{4}{*}{ LT } & Sphericity Assumed & 536.120 & 95 & 5.643 & & \\
\hline & & Greenhouse-Geisser & 536.120 & 95.000 & 5.643 & & \\
\hline & & Huynh-Feldt & 536.120 & 95.000 & 5.643 & & \\
\hline & & Lower-bound & 536.120 & 95.000 & 5.643 & & \\
\hline & \multirow{4}{*}{ SRS } & Sphericity Assumed & 973.078 & 95 & 10.243 & & \\
\hline & & Greenhouse-Geisser & 973.078 & 95.000 & 10.243 & & \\
\hline & & Huynh-Feldt & 973.078 & 95.000 & 10.243 & & \\
\hline & & Lower-bound & 973.078 & 95.000 & 10.243 & & \\
\hline & \multirow{4}{*}{ EFE } & Sphericity Assumed & 2401.979 & 95 & 25.284 & & \\
\hline & & Greenhouse-Geisser & 2401.979 & 95.000 & 25.284 & & \\
\hline & & Huynh-Feldt & 2401.979 & 95.000 & 25.284 & & \\
\hline & & Lower-bound & 2401.979 & 95.000 & 25.284 & & \\
\hline
\end{tabular}


There are differences of SRS among pre- and post- groups $[\mathrm{F}(1.00,95.00)=5.61, \mathrm{p}<0.05]$. New df1 $=$ 1.00 , New df2 $=95.00$. Pre- and post-EFE $[\mathrm{F}(1.00,95.00)=35.99, \mathrm{p}<0.05]$ also show there were increased in scores after treatments were given (as can be seen in Table 10 and 11, Figure 3, 4 and 5).

Table 11. Tests of Within-Subjects Contrasts for measuring LT, SRS and EFE.

\begin{tabular}{|l|l|l|c|c|c|c|c|}
\hline Source & Measure & PrePost & $\begin{array}{c}\text { Type III Sum of } \\
\text { Squares }\end{array}$ & df & Mean Square & F . \\
\hline \multirow{3}{*}{ PrePost } & LT & Level 1 vs. Level 2 & 12.760 & 1 & 12.760 & 1.131 & 0.290 \\
\cline { 2 - 8 } & SRS & Level 1 vs. Level 2 & 114.844 & 1 & 114.844 & 5.606 & .020 \\
\cline { 2 - 8 } & EFE & Level 1 vs. Level 2 & 1820.042 & 1 & 1820.042 & 35.992 & .000 \\
\hline \multirow{2}{*}{$\begin{array}{l}\text { Error } \\
\text { (PrePost) }\end{array}$} & LT & Level 1 vs. Level 2 & 1072.240 & 95 & 11.287 & & \\
\cline { 2 - 8 } & SRS & Level 1 vs. Level 2 & 1946.156 & 95 & 20.486 & & \\
\cline { 2 - 8 } & EFE & Level 1 vs. Level 2 & 4803.958 & 95 & 50.568 & & \\
\hline
\end{tabular}

Abraham et al. (1992), Skelly and Hall (1993), Baker and Piburn (1997), and Sanger and Greenbowe (1999) discovered that the environment, language, classroom materials, textbooks, students' attitudes to the subject matter, incompatibility of teaching approaches with students' learning styles caused alternative conceptions [10]. Some abstract Electrochemistry concepts are presented into concrete form in Post-SRS and Post-LT Tests to make them sense for learning. This also can be done with the help of diagrams.

The profile plots for pre- and post-LT, -SRS and -EFE as can be seen in Figure 3, 4 and 5.

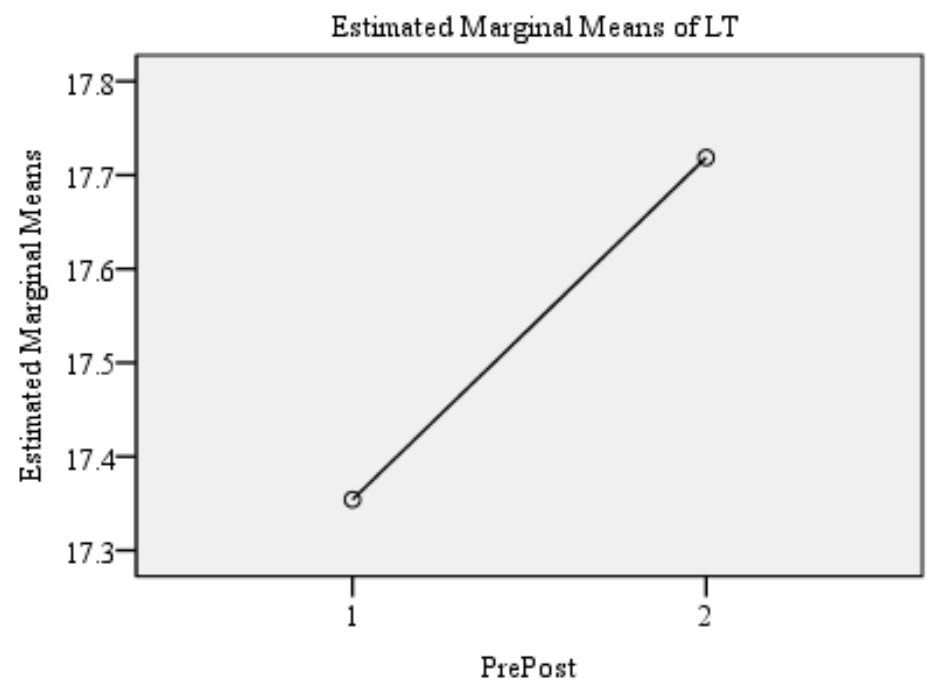

Figure 3. Estimated Marginal Means (EMS) for Pre- and Post-LT.

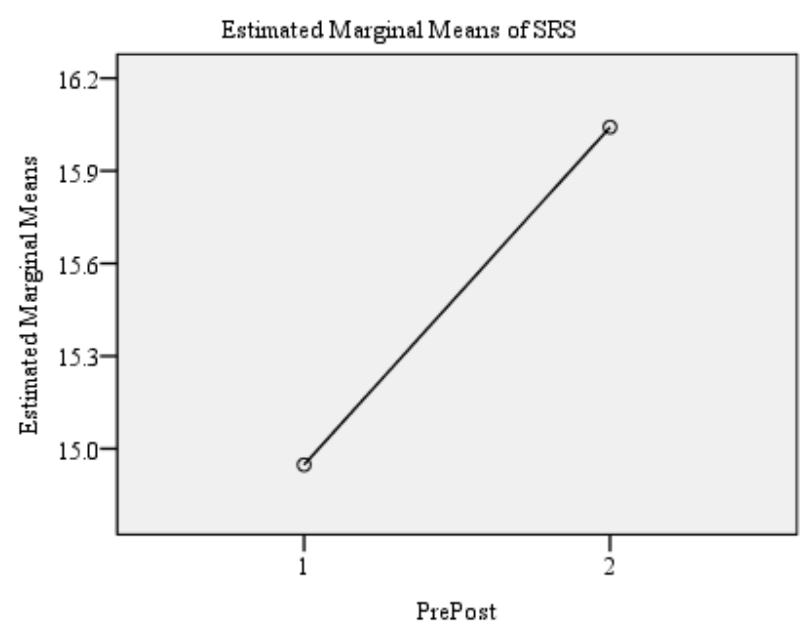

Figure 4. Estimated Marginal Means (EMS) for Pre- and Post-SRS. 


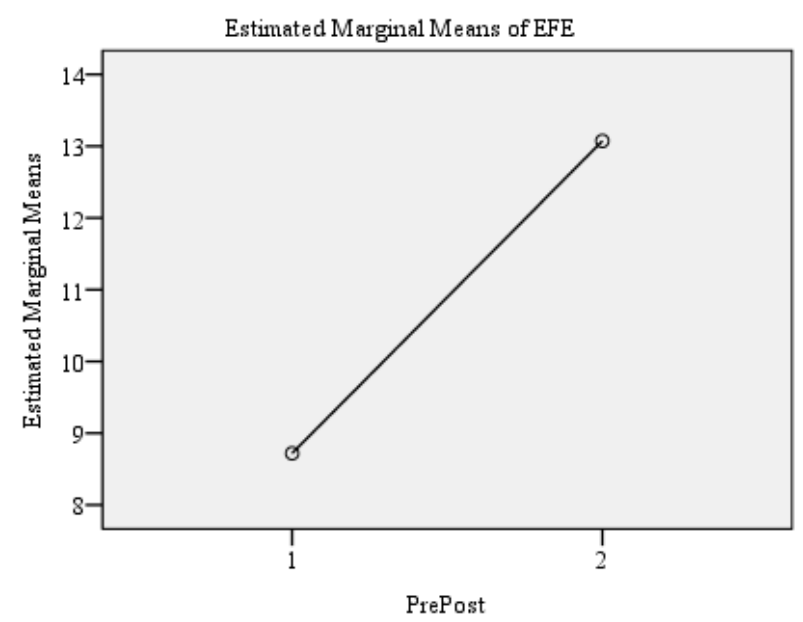

Figure 5. EMS for Pre- and Post-EFE.

\section{Conclusion}

Mostly, LM and ML did not give significant influence on Post-LT, -SRS, and -EFE. But, there are increasing in Post-LT, -SRS and -EFE scores compared to their Pre-Tests showing higher performances after treatments were given. LM and ML have no significant influence to Post-LT, -SRS and -EFE. For the next research, the focus is to facilitate the contents of Electrochemistry Form 4 Manual through diagrams or languages with adding more exercise. Each student will be provided with this manual to let them study alone (T \& L Aids centered) freely with no time constraints. The answers for each exercise will be spread through email. By using this way, hopefully all the limitations in this study will be solved.

\section{Acknowledgements}

Many thankful to all the participants that involved in this study especially to Cik Aifaa Bt Zulkifli, Pn. Kamariah Bt Mohamed Noordin, En. Kamarul Azizi B. Faisal, Pn. Zarina Bt Zakaria, my supervisors, School Principles, PPDLMS and students.

\section{References}

[1] David, G-C, et al., Dispositional flow in Physical Education: relationship with motivational climate, social goals, and perceived competence. J. Teach. Physical Edu., 28, 2009, $422-440$.

[2] Piaw, C. Y., Statistik Penyelidikan Lanjutan (KL, McGraw-Hill M'sia Sdn. Bhd.: 2009), 46.

[3] Calik, M., et al., Investigating the effectiveness of an analogy activity in improving students' conceptual change for solutions chemistry concepts, Intern. J. Sci. \& Math. Edu., 7, 2009, 651 - 676.

[4] Kang, S., et al., The influence of students' cognitive and motivational variables in respect of cognitive conflict and conceptual change, Intern. J. Sci. Edu., 27:9, 2005, 1037 - 1058.

[5] Pizzolato, J. E., et al., Struggling with self-study schematic dissonance and knowledge construction, College Teach., 57:3, 2009, $131-138$

[6] Ayub, A., Belajar Secara Berkesan di Sekolah (KL, Institut Terjemahan Negara Malaysia Bhd.: 2010), 124 - 146.

[7] Downloading from www.math.montana.edu on 30.Oktober.2013

[8] Lodewyk, K. R., et al., Relations among body size discrepancy, gender, and indices of motivation and achievement in high school Physical Education, J. Teach. In Physics Edu., 28, 2009, 362 - 377.

[9] Low, S. N., et al., KBSM Kimia Tingkatan 4 (Selangor, Abadi Ilmu Sdn. Bhd.: 2011), 96.

[10] Atasoy, B., et al., The effect of a conceptual change approach on understanding of students' chemical equilibrium concepts, Res. Sci. \& Technol. Edu., 27:3, 2009, $267-282$. 